\title{
Leang Lemdubu: Preliminary Report On Excavation Conducted By The Joint Indonesian-Australian Project, Prehistory Or The Aru Islands
}

Peter Veth; Matthew Spriggs; Susan O'Connor; Mohammad Husni; Widya Nayati

Keywords: cave, settlement, migration, prehistory, moluccas, australia

\section{How to Cite:}

Veth, P., Spriggs, M., O'Connor, S., Husni, M., \& Nayati, W. (1997). Leang Lemdubu: Preliminary Report On Excavation Conducted By The Joint Indonesian-Australian Project, Prehistory Or The Aru Islands. Berkala Arkeologi, 17(2), 1-7. https://doi.org/10.30883/jba.v17i1.757
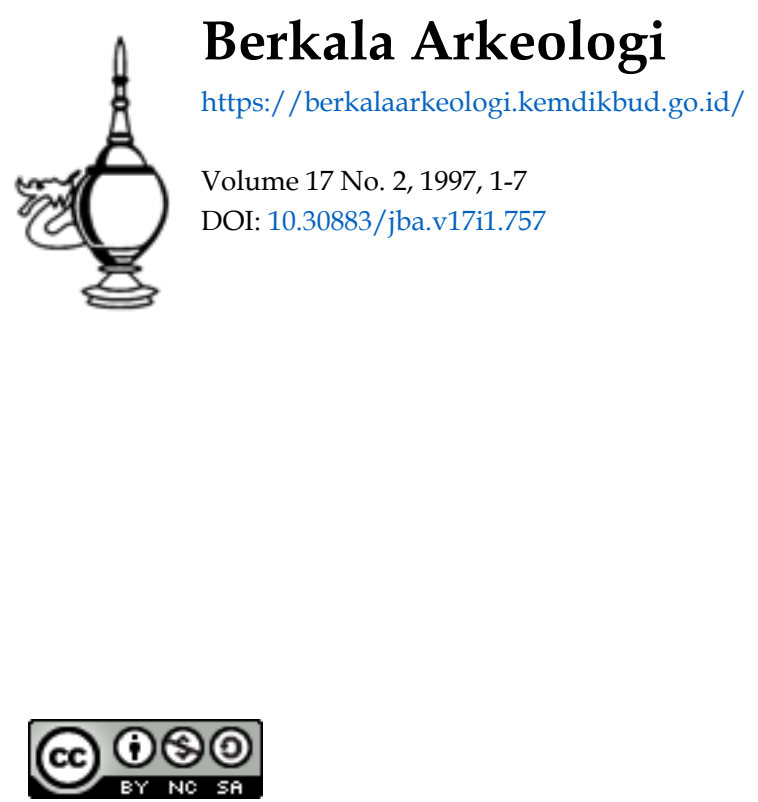

This work is licensed under a Creative Commons Attribution-NonCommercial-ShareAlike 4.0 International License. 


\section{LEANG LEMDUBU: Preliminary report on excavation conducted by the joint Indonesian-Australian Project, Prehistory of the Aru Islands}

\section{Peter Veth' ${ }^{1}$, Matthew Spriggs ${ }^{2}$, Susan O'Connor ${ }^{3}$, Mohammad Husni ${ }^{4}$, and Widya Nayati ${ }^{5}$.}

\section{Introduction}

In 1994 a small Australian Research Council Grant was obtained by one of the researchers (PV) to conduct archeological research into the prehistory of the Aru Islands. Liaison with Pusat Penelitian Arkeologi Nasional (PUSLITARKENAS) in Jakarta, Universitas Patimura in Ambon and relevant workers led to a joint Indonesian-Australian project finding formal expression in a Memorandum of Understanding between PUSLITARKENAS, James Cook University and the Australian National University. An initial reconnaissance survey on the Aru Island conducted during 1995 by Veth. Spriggs and Sujatmiko recorded nine significant sites. These sites comprised caves with evidence for prehistoric occupation, Neolithic coastal middens bearing ceramics and historic sites including a Dutch garrison and an early fortification/settlement. These result will be reported elsewhere (Veth et al. in press).

In 1995 a large Australian Research Council Grant was obtained and this will provide the necessary funding for three year collaborative project encompassing the systematic survey, recording and excavation of prehistoric sites in the Aru Islands. This paper reports on the nature and scope of prehistoric material recently excavated from a large cave on Pulau Kobroor, located within rainforest-covered karst limestone south of Sungai Manumbai. An exceptionally rich deposit of dietary fauna and stone artefacts characterises this site of probable Pleistocene age.

I James Cook University of North Queensland, Department of Anthropology and Archaeology, Townsville.

2 The Australian National University, Department of Archaeology and Anthropology, Faculty of Arts. Canberra.

3 The Australian National University. Division of Archaeology and Natural History, Research School of Pacific and Asian Studies. Canberra.

+ Balai Archeology Manado. Manado.

$5 \quad$ Gadjah Mada University. Archaeology Department. Faculty of Letters. Yogyakarta. 
The earliest evidence in the world for purposeful ocean voyaging comes from numerous Pleistocene-aged cultural deposits located within the Wallacean islands and Sahulland. It is assumed that these sites were produced by anatomically modem humans. That these early maritime colonists from Southeast Asia utilised competent watercraft should be beyond dispute given the combination of early dates greater than $30,000 \mathrm{BP}$ and degree of radiation to destinations such as Sulawesi, northern Australia and island Melanesia (cf. Veth et al. in press). The settlement of Manus, an island in the Admiralties located $200 \mathrm{~km}$ from the nearest land before 13,000 BP (Fredericksen et al. 1993), suggests some degree of sophistication in boat technology. It can be further argued that such technology would be rooted within a broad spectrum maritime economy which incorporated resources, as different landfalls were encountered.

The Aru Islands were connected to Greater Australia until approximately 8.000 years ago, when they were separated by rising sea levels. While now forming part of the Indonesian province of Maluku. for a long time they comprised an elevated land mass on the edge of the Sahul continent. The presence on Aru of numerous marsupials and the cassowary attest to this shared history. Indeed the biogeographical significance of the Aru Islands has long been highlighted by naturalists such as Wallace. While the waters to the east of the Aru Islands are relatively shallow, reflecting the previous landbridge with Irian and Northwest Australia. the continental shelf to the west slopes steeply with the $100 \mathrm{~m}$ isobath located as little as $10 \mathrm{~km}$ away. Due to their optimal position, the Aru Islands have the potential to register a multitude of maritime colonising events through time.

Aru was part of continuous landbridge to both Australia and New Guinea for at least the first 40,000 years of occupation of Sahul by $\mathrm{H}$. sapiens sapiens. It is only by approximately 12,000 years ago that rising sea levels begin to encircle the island group, separating it from Australia, and possibly as late as 8,000 to 9,000 years ago that it was completely separated from New Guinea.

The Aru Islands and their now-inundated Pleistocene coastal plains are located on two of the major colonising routes into Sahul, as proposed by Birdsell. Five possible colonising scenarios were proposed in this seminal paper. The first route of interest passes through Maluku via Buru, Seram and finally the Kei Islands with a landfall directly on the Aru uplands. The second route passes along the Lesser Sundas to Timor then via Maluku through Wetar. Babar and Tanimbar with landfall on Pleistocene coastline immediately southwest of the Aru group, perhaps within 100 $\mathrm{km}$. The Aru Islands would have represented the only elevated land mass within a radius of approximately $500 \mathrm{~km}$. The key point is that branches of the both the postulated primary northem and southem colonising routes pass through. or close to, the Aru lslands. 
The Aru Islands also have the advantage of being composed in part of limestone, with a substantial belt karst located near the central western coast. Rockshelters and caves occur in the karst and the alkaline environment has the potential to provide excellent faunal and botanical preservation. Another unique feature is the presence of substantial channels connecting the west and east coasts. These sungai not only connect major littoral zones, they also penetrate deep into the interior thereby providing easy access by watercraft to uplands and dense rainforest.

\section{An overview of research questions in Maluku prehistory}

A number of authors have recently identified archaeological research questions for Maluku (cf. Spriggs in press) These may be summarised as:

1. The timing and sources of Pleistocene settlement.

2. The nature of Austronesian settlement.

3. Papuan and Austronesian contact over the last 4000 years.

4. The history of the spice trade with China, India, and the West.

A number of salient points can be made at this stage to guide research on Aru.

- Given that the Aru Islands lie along branches of both the major colonising routes proposed by Birdsell, and given the antiquity of thermoluminescence and radiocarbon dates available from Melanesian and Australia, a 55,000 years history for Aru is likely.

- The widespread evidence for "hunter-horticulturalism" in New Guinea and Island Melanesia from at least 20,000 years ago is likely to be shared by Aru as it is within the range of a variety of important food plants, including sago. Hunter-horticulturalism describes an economy based on hunting and gathering, but which incorporates low intensity gardening and three cropping, deliberate movement of plants and animals across water gaps to more impoverished environments and long-distance exchange of valued items (Spriggs 1996).

- The dates for islands Southeast Asia Neolithic culture associated with agriculture and the spread of Austronesian languages suggest an age of 4,500-3,500 BP as likely for Neolithic settlement in the Aru group (Bellwood 1985). Assemblages of Neolithic type pottery and domestic animals such as the (hybrid) pig, dog and chicken are to be expected.

- The antiquity of the spice trade might be much older than the appearance of metal and Dongson drums in Maluku and the Bird's Head which, along with references in Chinese and Classical sources, are usually taken to mark its beginning about $200 \mathrm{BC}$ (Swadling 1996:22, 51-61). Dates of 3710-3550 BP have been claimed for cloves recovered from the ancient city of Terqa on the Middle Euphrates (Bucellati and Kelly-Bucellati 1977, 1977-1978). The significance of these dates is that they are from a period soon after Austronesian 
expansion. Spriggs (in press) has speculated that in fact part of the reason for Austronesian expansion may have to do with the extension of trading networks already operating on an (old) world scale. At this time the Austronesian sphere ran north through the Philippines. Taiwan and into South China.

The identification of the Tequa find a clove has, however, been disputed by other scholars (C. Lamberg-Karlovsky pers. comm. 1996). As Swadling notes (1996:22), written sources relating to clove $\mathrm{s}$ do not begin until some 1500 to 1700 years later.

Whether the spice trade began nearly 4000 or 2000 years ago, the archaeology of the Portuguese and Dutch colonial period must be seen as an appropriation of a much earlier global trading system. To spices. Swadling would add Birds of Paradise plumes as an early and significant component of this trading system. Aru was a probable early supplier of such plumes (Swadling. 196:62).

\section{Description of excavation at Leang Lemdubu.}

At the time of writing this report the researchers have just completed the excavation of Leang Lemdubu and are in the process of transporting archaeological specimens by prahu down Sungai Manumbai to the capital of the Aru Islands, Dobo. Therefore the following comments are provisional and are intended to reflect our field impressions rather than a detailed examination of cultural assemblages.

Leang Lemdubu is a large, double-entrance cave formed from an ancient subterranean river channel cut into karst limestone. It somewhat resembles a long tunnel with both ends truncated. It is approximately 30 meters in length, up to eight metres wide and is an average of three metres in height. The cave represents a height point on the local landscape and is surrounded by reasonably dense rainforest and swamps. It has a small hole in the central portion of the roof which clearly allows water and limited sediments to enter. This minor collapse appears quite recent. Stalactites and stalagmites occurs also in the central third of the shelter and where water drips from the former a considerable collection of Dutch and Chinese porcelain has been placed, being covered in a coating of calcium carbonate. These objects, and indeed the cave, are of adat significance and it should be noted that adat ritual and the continuos involvement of adat specialists was facilitated during the entire course of the excavation.

The densest concentrations of cultural materials on the extensive sediment floor of the cave are located near both of the driplines. Material includes shell midden. including the mangrove species Geloina sp.. Anadara sp. and Terebralia sp. Plain earthenware was also present, although in low numbers. Terrestrial fauna noted on the surface included deer, pig, kangaroo and possibly cuscus. A low density of stone artefacts were recorded. although it became clear that many of the large Geloina 
valves had been retouched/utilised and had therefore probably also served as artefacts.

Our initial assessment was that the deposits immediately inside the driplines at both ends of the cave were likely to be the deepest and the least disturbed by water action, roots and major roof fall events. Our method was to excavate in five centimeter spits. wet-sieving all materials through fine mesh $(1.5 \mathrm{~mm})$. record volumes of recovered materials and to sort all cultural residues. Initially a $1 \times 1 \mathrm{~m}$ test-pit (Test-pit 1) was dug at the west end of the cave. This reached bedrock at approximately $50 \mathrm{~cm}$ below surface level. The test-pit revealed a homogeneous loose gray-brown sediment which changed to an orange-brown mottled clay immediately above bedrock. The Upper Unit contained charcoal, terrestrial fauna, earthenware, marine shellfish. a fragment of metal and stone artefacts. The Middle Unit lost the shellfish but contained terrestrial fauna, stone artefacts and minimal charcoal while the Lower Unit comprised sparse assemblage of fauna and the occasional stone artifact. From this first test-pit it become apparent that the deposits of Lembudu contain a phenomenal quantity of terrestrial fauna, reflecting resources from a wide range of habitats within the rainforest system.

Test-pit 2 was located near a massive in situ boulder at a mounded portion of the deposit at eastern end of the shelter. To some extent this excavation represented an expanded version of Test-pit 1 . The excavation of $1 \times 1 \mathrm{~m}$ reached sterile deposits at $>160 \mathrm{~cm}$ below surface level and contained a remarkable quantity and range of terrestrial fauna. For example, Spits 24 and 25 each yielded 14 medium-sized bags of bones. Much of this materials is in a good state of preservation and includes a substantial amount of cranial material and teeth which may be used to identify species and possibly indicate the existence of now extinct species. As expected, a major marsupial component was seen through the presence of small to medium sized wallabies (marcopods), cuscus (phalanger), bandicoot and native cat (dasyurids). Lizards, snake, cassowary (both bone and shell) and dog are also present. The faunal assemblages represent the most extensive and dense ever experienced by the researchers in the Indo-Pacific region.

Dating the deep deposits of Test-pit 2 will be facilitated by the presence of charcoal and marine shellfish down to Spit 7, the occasional occurrence of marine shell or charcoal through to Spit 25 and two flowstone features which occur between Spits 27 and 30. Fauna appears to have been discarded due to human agency down to Spits $28 / 29$. The minimal faunal remains from basal Spits 30 and 1 is assumed to be due to natural agencies. The lowest stone artifact was recovered from Spit 29 and this is bracketed by the lower flowstone layer.

While it is impossible meaningfully to estimate the age of the deposit, the fact that marine shellfish are effectively lost by Spit 8 (circa 6.500 BP?) and that geological features (two separate flowstone layers) bracket the base of the deposit and the 
extremely dense faunal assemblage all suggest a Pleistocene antiquity for the site. Key samples of marine shellfish. charcoal and flowstone will be submitted for dating over the next several months.

The excavations have also yielded sizable assemblages of stone artifacts which may also be reliably dated through time. There appear to be long-term continuities in to technology of artifacts production, in that the industries are essentially percussion flake based. with the modified component represented simply by retouched/utilized flakes. There are no grounds 10 argue for specialized scraper categories or the later appearance of a small tool component, and certainly no indication of the Hoabhinian. There do appear to be consistent changes in the dominant lithologies used through time, however. with silicified calcretes. cherts, silcretes, chalcedonies and even possibly obsidian, all making appearance. The flake stone technology is therefore very similar to key Pleistocene sites excavated from Northern Australia (cf. papers in Veth and Hiscock 1996).

Our field observations suggest that Leang Lembudu is a most significant site for understanding the shares history of northern Australasia and island Southeast Asia. It will likely provide early dates for the systematic exploitation of rainforest ecosystem (see also Pavlides and Gosden 1994), show shared material cultural attributes with early sites in northern Australia and witness the deliberate use of hinterland resources by coastally adapted peoples.

It is appropriate that the archaeology of the Aru Islands, located as they are on a biogeographical bridge between island Southeast Asia and Australia, should be investigated by a joint Indonesian-Australian research team. 


\section{Bibliography}

Bellwood. P.S. 1985, Prehistory of the Indo-Malaysian Archipelago. Sydney: Academic Press.

Fredericksen, C. M. Spriggs and W. Ambrose 1993, Pamwak Rockshelter: a Pleistocene Rockshelter on Manus Island, PNG. In M. Smith, M Spriggs and B. Fankhauser (eds.) Sahul in Review: Pleistocene Archaeology in Australia, New Guinea and Island Melanesia, pp. 144-152. Canberra: Department of Prehistory, Research School of Pacific Studies, Australian National University. Occasional Papers in Prehistory 24.

Modern Quaternary Research in Southeast Asia. Rotterdam, Balkema Press.

Pavlides, C. and C. Gosden 1994, 35,000 Year Old Sites in the Rainforests of West New Britain, Papua New Guinea, Antiquity, 68:604-610.

Spriggs M. in press, Research Questions In Maluku Archaeology. Paper given at the Third Maluku Studies Conference, Universitas Pattimura, Ambon, July 1994, revised September 1996.

Spriggs. M. 1996, Agriculture and What went Before in Island Melanesia, in D. Harris (ed.) The Origins of Agriculture and Pastoralism in Eurasia, pp.524-537. London: UCL Press.

Swadling. P. 1996, Plumes from Paradise: Trade Cycles in Outer Southeast Asia and their Impact on New Guinea and nearby Islands until 1920. Port Moresby: PNG National Museum, in association with Robert Brown and Associates (Qld).

Veth. P. and P. Hiscock 1996, Archaeology of Northern Australia: regional perspectives. Tempus Archaeology Series 4, Anthropology Museum, University of Queensland, Brisbane.

Veth, P. M. Spriggs, A. Sujatmiko and S. O'Connor in press, Bridging Sunda and Sahul: the archaeological significance of the Aru Island, Maluku. 